\title{
Vincent Vives, Hypatie et Hérodiade. Dialogue sur la poésie entre Leconte de Lisle et Mallarmé
}

\section{Mario Richter}

\section{(2) OpenEdition}

1 Journals

\section{Edizione digitale}

URL: http://journals.openedition.org/studifrancesi/36531

DOI: 10.4000/studifrancesi.36531

ISSN: 2421-5856

\section{Editore}

Rosenberg \& Sellier

\section{Edizione cartacea}

Data di pubblicazione: 1 juillet 2005

Paginazione: 192

ISSN: 0039-2944

\section{Notizia bibliografica digitale}

Mario Richter, «Vincent Vives, Hypatie et Hérodiade. Dialogue sur la poésie entre Leconte de Lisle et Mallarmé», Studi Francesi [Online], 145 (XLIX | I) | 2005, online dal 30 novembre 2015, consultato il 18 avril 2021. URL: http://journals.openedition.org/studifrancesi/36531 ; DOI: https://doi.org/10.4000/ studifrancesi.36531

\section{Questo documento è stato generato automaticamente il 18 avril 2021.}

\section{(c) (1)}

Studi Francesi è distribuita con Licenza Creative Commons Attribuzione - Non commerciale - Non opere derivate 4.0 Internazionale. 


\title{
Vincent Vives, Hypatie et Hérodiade. Dialogue sur la poésie entre Leconte de Lisle et Mallarmé
}

\author{
Mario Richter
}

\section{NOTIZIA}

VINCENT VIVES, Hypatie et Hérodiade. Dialogue sur la poésie entre Leconte de Lisle et Mallarmé, in «Bulletin d'Etudes parnassiennes et symbolistes», n²6, Automne 2000, pp. 25-43.

1 Attraverso un esame essenziale e chiaro del poemetto Hypatie et Cyrille di Leconte de Lisle e della mallarmeana Hérodiade, l'A. mette efficacemente in luce il diverso atteggiamento tenuto dalle due personalità poetiche di fronte alla funzione della poesia e alla Storia. Vincent Vivès dimostra, come egli stesso premette, che "Hypatie et Cyrille engage la poésie dans une pensée historiale qui cherche à renouveler l'épopée et à rompre avec la dynamique romantique», mentre «Hérodiade, par sa structure et son discours, est une réponse du prince des Poètes au prince du Parnasse, à travers laquelle il fixe son esthétique nouvelle - postérieure à la période dominée par l'influence baudelairienne - et prend ses distances avec le modèle esthétique des Poèmes antiques». 